\title{
Balkan and European? Place Identifications of Young People in Croatia
}

\author{
Alistair ROSS \\ London Metropolitan University, United Kingdom \\ alistairrosslondon@gmail.com \\ Saša PUZIĆ \\ Institute for Social Research in Zagreb, Croatia \\ puzic@idi.hr \\ Karin DOOLAN \\ Department of Sociology, University of Zadar, Croatia \\ kdoolan@unizd.hr
}

The article analyses how young people in Croatia conceptualise their identities in terms of "place identifications", a type of social identification that captures membership of a group of people who are defined by their location. It is based on focus group discussions conducted with 68 elementary and secondary school students aged between 11 and 17 in three urban localities in Croatia: Rijeka, Zagreb and Zadar. The concepts guiding the analysis included place identifications, the civic and cultural components of national identity and intersectionality. The study found that students displayed a strong identification with the region they are from through a discourse of stereotypes along the coastal-inland, rural-urban and north-south distinctions. National cultural identities and liminal European-Balkan identities were equally strong providing interesting examples of inclusion and othering. The young people showed a sense of aspiring to be European, of feeling almost European, of being not-quite-yet European, of being "Balkan". There was a common sense of the Balkan-European divide being a line that stood very slightly to the north-west of wherever the students happened to be: there was Europe, generally beckoning - but they were on a threshold and still leaning towards the Balkan side, described as impolite, quarrelsome, underdeveloped and littered. The study suggests complex and kaleidoscopic identity constructions of young people in Croatia in which different and even opposed elements do not exclude each other but rather coexist in various ways.

Key words: place identification, civic and cultural identities, intersectionality, youth, Croatia, Balkans, Europe 


\section{Introduction}

Twigger-Ross and Uzzell (1996) have written on people's expressed identification with a particular place, using the concept of "place identifications" as a type of social identification which captures membership of a group of people who are defined by their location. ${ }^{1}$ People's relationships to different places have already been the focus of several studies in Croatia. For instance, Sekulić and Šporer (2008) have analysed the intensity of attachment adults in Croatia have to their place of living, specific county and region, Croatia as a whole, a particular region in Europe as well as Europe more generally. Their results showed that people generally feel the strongest attachment to the national level, followed by those expressing a very close attachment to their more immediate place of living, while the weakest attachment was felt to Europe and its particular regions. The authors discussed positive correlations between attachments to Europe and Croatia, suggesting that the attachment to Europe does not replace or exclude national identification, but can be seen as part of a process of broadening the identity space. Research on youth identities in Croatia has shown that national identification has become stronger in the post-socialist period (Baranović, 2002; Radin, 2005), although the intensity of this identification varies with respect to young people's family background, residence status (urban vs. non-urban) and religiosity. In general, stronger national identification prevails among the religious youth, those from rural or less developed areas, those from lower socio-economic family backgrounds, and especially those whose parents have lower levels of education. Importantly, attitudes that reflect openness to other nations have remained relatively stable suggesting that strong national identification can coexist with an acceptance of cosmopolitan values. In line with this, data from 2012 (Ilišin et al., 2013) showed that a majority of young people in Croatia supported Croatia's accession to the EU and that positive expectations from the EU

\footnotetext{
${ }^{1}$ This paper is part of a larger project investigating how young people conceptualise their identities in a string of countries that have either joined the European Union (EU) in the 2004-2013 expansion, or have been candidate countries to become members - some 15 countries, from Iceland and Estonia in the north, through east and central Europe, the Balkans, to Turkey and Cyprus in the south (Ross, 2015). The project was undertaken partially with support from a Jean Monnet ad personam Chair, awarded by the European Commission to the first author, and was partly unfunded. Croatia is the only country to have actually moved from candidate status to full membership during the course of this study, and was not a member at the time of the fieldwork in Croatia in October 2012.
} 
prevailed over the negative ones. This finding is consistent with research on the multiple identities of 18-24-year-olds in six European countries (Austria, Czech Republic, Germany, Slovakia, Spain and the United Kingdom) which shows a positive correlation between European identity and national or other place identifications (region of residence or birthplace) (Boehnke and Fuss, 2008). However, along with the aforementioned "optimistic" view of joining the EU, young people in Croatia have also expressed euroscepticism, particularly in relation to their future socio-economic status in the wider EU region. According to Baranović (2002: 138), young people in Croatia expressed an image of Europe that "is ambiguous and varies from a synonym for progressive and civilised to a source of danger and threat". The research presented in this article on how young people in Croatia identify with "places" at different levels of abstraction, which was conducted on the cusp of Croatia's accession to the EU, has some resonance with this conclusion.

The presented analysis expands the existing research on youth in Croatia in various ways. While past research was mainly quantitative in nature, our study analyses qualitative data gathered from focus group discussions in order to address the underresearched issue of multiple identities of young people in Croatia, or more specifically, the European, national and other place identifications of elementary and secondary school students from various Croatian regions. Consistent with its topic of interest, the study combined various theoretical concepts that capture the broad area of identity issues, and which have not been used together in previous research on young people in Croatia.

\section{Guiding concepts}

Along with place identifications, we use the distinction between the civic and cultural components of identity as well as intersectionality to capture how the young people we talked to in Croatia relate to different "places": their immediate locality, regional affiliation, Croatia, the Balkans and Europe. The term "Balkan" is both a geographical and a cultural construction (Wolff, 1994; Todorova, 2009 [1997]), and we use it here loosely to refer to the expressions used by young people in the study. The Balkans have for many years had a particular aura among Western Europeans. Maria Todorova (2009 [1997]) has written of the manner in which the Balkans have been imagined: the development over several centuries of an insidious 
intellectual concept of an identity that denied the region's European character. Western Europe, she claims, has "expropriated the category of Europe, with concrete political and moral consequences" (Todorova, 2009 [1997]: 202). Todorova draws on post-colonial theory to examine how the region has been positioned in a variety of discourses: In particular, she analysed the disparagement of the Balkan identity in a form of reductionism that has allowed "the Balkans" to be peopled by "inhabitants [who] do not care to conform to the standards of behaviour devised as normative by and for the civilised world" (Todorova, 2009 [1997]: 3). The concept of the Balkans has been used in a derogatory manner to describe fragmentary and incoherent mini-states, impetuous and impulsive nationalism, powder-keg politics. Balkan has come to mean not-properly-European.

The concept of Europe is in many ways ambiguous and "terminologically confusing" (Connor, 1978: 386). In much the same way that Renan wrote of a people having "many things in common, but [...] also forgotten much together" (Renan, 1994 [1882]: 17), it has been observed that post-1945 Europe "was able to rebuild itself politically and economically only by forgetting the past, but it was able to define itself morally and culturally only by remembering it" (Menard, 2005). As Judt puts it in Post War: "silence over Europe's recent past was the necessary condition for the construction of a European future" (Judt, 2005: 10). European identity has become part of the palimpsest identity described by Bauman (1997: 25), one "which fits a world in which the art of forgetting is an asset".

The distinction between different kinds of European identity has been systematically analysed by Michael Bruter (2005; also Bruter 2003, 2004, 2008a, 2008b, 2009), who derives two components of identity within political communities. "A cultural perspective would analyse political identities as the sense of belonging an individual citizen feels towards a particular political group. This group can be perceived by him to be defined by a certain culture, social similarities, values, religion, ethics or even ethnicity $[\ldots]$. A civic perspective would see [...] the identification of citizens with a civic structure, such as the State, which can be defined as the set of institutions, rights, and rules that preside over the political life of the community" (Bruter, 2005: 12). Bruter contends that these two components exist in parallel in citizens' minds, and need to be differentiated when possible. An individual may have stronger civic or cultural elements to their (European) identity, with differences between individuals, countries and over periods 
of time. Using a questionnaire with UK, French and Dutch respondents, he offered empirical support for the existence of "a civic component [...] [that] makes people identify with the European Union as a significant 'superstate' identity, and [...] a cultural component that makes people identify with Europe in general as an area of shared civilisation and heritage" (Bruter, 2005: 114). His respondents gave greater salience to their European civic identity, speculating that a common European heritage might be too much of an abstraction.

The differentiation between cultural and civic elements is core to the analysis of young people which follows, both of their identification with Europe and their identification with their country. It will become evident that the two competing poles of the cultural and the civic jockey for position contingently and temporally in the ways that young people construct and use their identities (Waldron, 2000; Stevick and Levinson, 2007; Ichilov, 2005). This cultural-civic distinction also helps in understanding the ways in which otherness is constructed in the feeling of an identity. Boundaries and markers may be constructed in an exclusive way, or may be permeable (Schlenker, 2007).

Finally, we have found it useful to draw on theories of intersectionality to examine how young people describe their place identifications. McCall (2005: 1171) defined intersectionality as "the relationship among multiple dimensions and modalities of social relations and subject formations", encompassing "perspectives that completely reject the separability of analytic and identity categories" (McCall, 2005: 1171, footnote 1). The traditional axes of identity used in intersectionality are gender and race (Crenshaw, 1991), to which social class and ethnicity have often been added. Identity formation is not based on each of these factors being independent of the other: they interrelate and intersect to create multiple forms of oppression and discrimination (Ritzer, 2007 [2003]). The literature on intersectionality has informed our study by directing our attention to multiple, intersecting levels of place identifications: we assumed that they are structured in part by dimensions of nationality and regionalism, as well as Europeanisation. We use these existing categorical distinctions and at the same time question their utility and relevance in the contemporary context. In addition, we expected that these identities would be shaped by each other to create a tangled and complex nexus of more or less exclusive group identities. 


\section{Study methodology}

As noted earlier, the data on Croatia analysed here was gathered as part of a larger study by the first author, encompassing all the countries that had joined the European Union since 2004 and the candidate states in accession negotiations (Ross, 2015). This study examined the ways in which young people socially construct identities that may encompass the local, national, regional, European or global, or some or all of these, in varying degrees, and examined their discourse of managing multiple identities within these various political "places". Kristeva has asked how the European Union can be "meaningful and not just useful" (Kristeva, 2000: 118). Part of this study was to examine the various meanings that were attached by these young people to their country of residence and to Europe, and to any possible intermediary identities such as the Balkans (the larger study also included Slovenia, Macedonia and Bulgaria). The issues this larger study sought to address included examining which "places" young people in each country identified with; noting if they acknowledged a multiplicity of place identifications, or whether their narratives were singular and essentialist in terms of place; examining whether the place identifications they used required them to construct "the Other", an alien identity held in juxtaposition to their own identity, and if so, what they thought were the borders to this "otherness". The study also sought to address the extent to which young people in each country identified with the cultural and civic aspects of Europe, and how this related to their use of these components in their identification with their country. The discourses by which the young people both contested and reflected on these political identities can contribute to understanding the processes of Europeanisation and globalisation, and the relationship between them (Delanty and Rumford 2005: 6; Castells 2000 [1996]: 348).

Since this study explored how young peoples' identities are socially constructed in relation to place, and because social constructions are relational and created through interaction in a social context, we have used focus group discussions as the data source (Marshall and Rossman, 1999). The centrality of shared social constructions makes focus group discussions an appropriate research tool which enables multiple voices to be "heard", while reducing the necessity for potentially distorting interventions by the researcher whose role is more of a mediator. Therefore, the choice of focus groups as the study's method was guided by the expectation that young peoples' own constructions would more spontaneously emerge from the 
discussions and interchange with their peers, although we are aware of the limitations of such an approach. These include the risk of participants not feeling comfortable with each other which can shape their willingness to speak or what they say (Smithson, 2000).

The focus groups took place in October 2012, some nine months prior to Croatia's EU entry, in three urban locations (Table 1). These gave a geographical spread of about $300 \mathrm{~km}$ that included three different historical regions (one continental /Zagreb/ and two coastal regions, Primorje /Rijeka/ and Dalmatia /Zadar/), but we did not visit any rural schools.

Table 1. Study sample by location, number of schools and focus groups as well as dates of field work

\begin{tabular}{lcccccc}
\hline locations & schools & groups & $\begin{array}{c}\text { female } \\
\text { students }\end{array}$ & $\begin{array}{c}\text { male } \\
\text { students }\end{array}$ & $\begin{array}{c}\text { total } \\
\text { students }\end{array}$ & $\begin{array}{c}\text { dates of focus } \\
\text { groups }\end{array}$ \\
\hline Zadar & 2 & 4 & 11 & 11 & 22 & 16 Oct 2012 \\
\hline Rijeka & 2 & 3 & 10 & 8 & 18 & 17 Oct 2012 \\
\hline Zagreb & 2 & 4 & 14 & 14 & 28 & 18 Oct 2012 \\
\hline total & 6 & 11 & 35 & 33 & 68 & \\
\hline
\end{tabular}

In each location two schools with different social mixes were selected. In one location (Rijeka) focus group discussions were conducted with three groups of 11-14 year-olds, and in two locations (Zadar and Zagreb) with four groups of 14-17 year-olds. The basic criteria for choosing the schools at which focus group discussions were conducted was school type, as we had to select one gymnasium and one vocational school at each location the exception were the schools in Rijeka with one elementary school and one gymnasium. Gymnasiums represent the principal gateway to higher education in Croatia, while vocational schools provide different types of technical knowledge as well as qualifications for skilled workers and craftsmen.

The students who attended the focus groups were selected by the teacher who was the research team's main school contact. Permission was sought from the young people and, for those under 16, from their parents. We tried as far as possible to include an equal number of males and females. We were not concerned with legal nationality or status, but with young people whose home is now in the country. We tried, by demeanour, expression and question, to make it clear that we respected what they had to say. All focus groups were led by the same researcher (the first author) with the support of a co-moderator who was a different person in each of 
the three locations. The co-moderator provided interpretation support where necessary, and provided contextual information on local contingent references made by the young people; they also liaised with the schools.

The opening question was designed to emphasise the open-ended nature of the discussion that was to follow: "How would you describe yourself? What would you say your identity is?" Other issues followed: "Do you ever describe yourselves in other ways?", "Does being in Europe affect the way you think about your identity, and your future?", "What is particular or different about Europeans?".

Discussions were transcribed and examined and systematically analysed against a country-specific index of themes built partly on the cultural-civic perspectives of Bruter's study (2005), partly on Todorova's analysis of the concept of the Balkans, partly on country-specific literature (Sekulić and Šporer, 2008; Baranović 2002), and partly on the groups' specific narratives (Rabiee, 2004). The themes for the Croatian analysis thus reflected both the general themes that were common to all the countries in the wider study (cf. above), and specific aspects of both the Croatian and Balkan culture.

Ethics approval was given by the Research Ethics Committee of the lead author's institution, and the overall design followed the ethical guidelines of the British Educational Research Association. The young people and their parents were informed in writing in advance about the nature of the study, and invited to participate. They were informed that all identities would be anonymised, and that an audio recording would be made of the discussion. Written permission from both parents and the young people was obtained. The average length of each discussion in Croatia was 45 minutes (the longest was 68 minutes and the shortest 32 minutes). All the authors have been involved in the present analysis. The project would not have been possible without help from many people, to whom we are indebted. ${ }^{2}$

\section{Findings}

\subsection{Regional and national identifications: prejudice and divisions}

A vital part of social identity constructions is the "process of differentiation and demarcation by which the line is drawn between 'us' and 'them"”

\footnotetext{
${ }^{2}$ Branislava Baranović, Iva Buchberger, Bojana Ćulum, Ivana Jugović, Iva Košutić, Vesna Kovač, the heads/principals of the schools and the students.
} 
(Lister, 2004, in Jensen, 2011: 65). These differentiations, which determine social identities as the same or different from the "Other", are often paralleled by stereotypical reasoning with regard to in-group and out-group relations. Stereotypes express beliefs about the characteristics and behaviours of certain groups (Hilton and Von Hippel, 1996). In doing so, they affirm group identity by ascribing homogeneous traits to members of the in-group as well as to members of other groups regardless of the actual variation among members of the concerned groups (Bar-Tal, 1997; Koren, 2013). Divisions accompanied by stereotyping and prejudice both within Croatia (north-south-other, inland-coastal, rural-urban) and in reference to neighbouring countries ran through the focus groups. In Zadar, Josip P (male /M/, 151/2) said: "People in the south have more temperament, but they are also lazier than the ones in the north. There's a big difference from the rest of Croatia. There are also Istrians in Istria - who are very different from the ones in the north and the south". A group in another school in Rijeka saw people from Primorje (the northern coastal region) as different from "other" Croatians. Zrinka B (female /F/, 141/4) said: "When it comes to arriving on time, or the dress codes, or something, we're more casual. We think it's OK to be late, that's what we're like on the coast". Tomislav $\mathrm{S}\left(\mathrm{M}, 13^{1 / 4}\right)$ added that dialects, cultures and dress codes were different from what he called "the people who are continental". The continental part of Croatia, Jasenko B (M, 121/4) said (and the others agreed) began after Karlovac (a town on the road to Zagreb).

Beyond this, Zrinka B (F, 141/4) claimed the people from the countryside were technologically less sophisticated, raising animals and inwardlooking - while "we're from the sea, ${ }^{4}$ we're kind of more outgoing, more familiar with technology. I don't know if you can say we're better educated". Paerrgaard (1997, in Wiborg 2004) has made a distinction between "rational/negative" and "nostalgic" conceptions of rural spaces where the former is characterised by "an image of the village as undeveloped with ignorant people far from modern society" and the latter as "the rural village as a picturesque setting unspoilt by modern society's negative influence" (Wiborg, 2004: 427). Zrinka B's response illustrates the former.

\footnotetext{
${ }^{3}$ All names are pseudonyms. These are not always the same pseudonyms that were used for the same data in Ross (2015), because the dataset for the full 2000-person study has been revised to prevent the duplication of pseudonymous names.

${ }^{4}$ Meaning in the context "coastal people".
} 
The use of "we" as opposed to "they" in the above quotes illustrates well the students' perceptions of regional differences and their own positive understanding of themselves in terms of these differences. Whereas people on the coast are constructed as "casual", "mobile", "outgoing", "technologically savvy", inland people are implicitly or explicitly positioned as formal, static, with those from villages being "less familiar with technology" and "less educated".

The discourse of regional divisions was also evident in a group in a Zagreb gymnasium. Roko L (M, 14/3) spoke of the Slavonians (in the east of Croatia, towards the border with Serbia) as poor agriculturalists beset by droughts (there had been a particularly serious drought over the summer before this discussion, with agricultural production in Slavonia and other areas of the Balkans reduced by over 50\%): "When the conditions are not satisfactory, they have more concrete problems - they can't feed their children, and that's the issue for them". Radoš B (M, 14\%/4) sympathised: "[...] for them it's more important to love your family than to love your country, because the country is not a concrete thing - it's more abstract than your family". This provoked a debate. Karlo C $(\mathrm{M}, 15)$ disagreed that the Slavonians might feel less love for their country: "Because the parts of Croatia that were most affected by the war - like Slavonia, Lika - they saw the horror, they saw dead people, they saw their enemies, they saw their families being killed. But in the parts of the country that the war didn't affect - cities like Pula, Varaždin - they are much more developed, and [...] they weren't on the battleground. The areas that were most destroyed are the areas where the people like the country the most". Zvjezdana C (F, 143/4) said: "I agree with Karlo. Someone from Vukovar loves Croatia a little bit more - they know what happened there - we all know what happened there, but they witnessed it. But I think we should learn a little bit more in school about that war". In these quotes war becomes interwoven with (under)development and patriotism. ${ }^{5}$

What the above excerpts illustrate is students' strong regional identification grounded in stereotypes about other regions. It can be noted that these stereotypes are not unambiguous in themselves, and that students'

\footnotetext{
${ }^{5}$ How to teach about the Homeland War has been a controversial issue in Croatia. According to Marić (2016: 106), teaching plans and programs for history in Croatia promote "an ethnically biased, closed and militarily focussed narrative", although since 2009 certain authors of approved history textbooks have "managed to include perspectives that are neglected or even silenced in the dominant narrative of the war".
} 
understandings of regional identities refer to various forms of social differentiation. The Rijeka students talked about even more precise differences, between those people who live less than five kilometres from Rijeka. Danijela F (F, 15\%/4) lived in Grobnik, $5 \mathrm{~km}$ away: "People there are not open-minded [...] they see Rijeka as something bad, and themselves as superior". Agata N (F, 173/4) lived in one of a trio of small villages $8 \mathrm{~km}$ to the south: "We can't stand each other - Hreljin, Krasica and Bakar. There's only a kilometre between us - we say 'Oh, from Bakar - we won't talk about them'. [But] We are together when it's Rijeka, when it's Rijeka against Zagreb". The students' narratives suggest attachment to their local communities, which is permeated by inter- and intra-regional prejudice and divisions. But there are other narratives, equally strong, of both national cultural identities and of liminal European-Balkan identities.

In terms of national identity, in Zadar there was reference to the Homeland War being a reason to feel proud of one's country. Thus Adrijana M (F, 151/2) said "a lot of people died in the war, and we should be proud that we are Croatian. And I think the people who say they are ashamed to be Croatian are very bad, they shouldn't say that, because a lot of people died there, and sacrificed themselves for this country, so that someday people could live here and have a normal life - I think that we absolutely have to be proud of who we are and that we come from here. We must be proud". Zadar had been in a war zone: Rijeka had not. Zorka V (F, 16²/2) from Rijeka made this point: "About the war, Croatia-Serbia. I think that the people in schools today are all so proud of that war, like they were there and were fighting for their country - but it wasn't actually them." She went on to criticise nationalism: "I don't think being born on this particular piece of land gives me any advantages over anyone who wasn't [...] I'm completely against nationalism. A lot of people from Rijeka and Croatia are very proud of their country - more than they should be. We in the Balkans [...] have some of the more nationalist-orientated people in the world, and this is not always a good thing, because this leads to hate and intolerance".

This was echoed in the Zagreb gymnasium. Radoš B (M, 14³/4) said that Serbs, Bosnian-Herzegovinians and Croatians were "all very similar", and it was not sensible to dwell on differences. He went on to say he was Croatian simply because his language was Croatian: "It's not a big deal it's nothing". But Vanda P (F, 15) disagreed: "When you accept the culture of the country you are in, then you are from that country. We are Croatians 
because we act like Croatians, we speak Croatian - we do things that are normal for Croatian people, and that's what makes us Croatians". Similar to earlier references to students' regional identities, these excerpts suggest national identity formation as a process touching upon different forms of social differentiation with war experience as one central demarcation line. Consistent with these relational viewpoints on identity formation are the expressed understandings of national identity, which includes both relativistic and essentialist perspectives. While some students whose parents had been combatants in the war (Adrijana M, Vanda P) expressed a sense of national belonging that is culturally defined and exclusive, others whose parents had not been directly involved in the conflict (Zorka V, Radoš B) leaned towards a more universalistic outlook compatible with Bruter's (2005) civic aspects of national identity. Together with the aforementioned layers of regionality and locality, these various forms of national identification express intersecting levels of exclusion and inclusion.

\subsection{Exclusion and inclusion within the Balkans}

"Us" and "them" divisions went beyond past war experiences and included sports as a playing field for acting out regional and international rivalries. The following excerpt by Agata N (F, 17\%/4) from Rijeka illustrates such tensions:

"I think we are all proud of [Croatia] - but again, we are not friendly towards Serbians or Slovenians - we hate Slovenians - but again, we don't like each other in Croatia - I think it's like we are in Croatia, but we are separated in a lot of ways - we don't like people from Zagreb, because they are Purgeri, or people from Split or Dalmatia we call Tovari [laughter from others]. ${ }^{6}$ Well we do! We can't stand each other, and we can't stand other people. I don't know how we can live like this! And I think mostly it's because of sport. It started with Dinamo-Rijeka ${ }^{7}$ - we can't stand them, they can't stand us - I don't know".

\footnotetext{
${ }^{6}$ Purgeri (from German Bürger) are families with a tradition of living in Zagreb over several generations: it has a negative connotation when used by people from outside of Zagreb to address Zagreb residents in general. Tovari (meaning donkeys in Dalmatian dialect) is a northern Croatian term for people from Dalmatia, and is often used with reference to football teams.

${ }^{7}$ GNK Dinamo Zagreb, football club from the Croatian capital Zagreb, and HNK Rijeka, football club from the town of Rijeka.
} 
Discussions of Serbs provided interesting examples of inclusion and othering. There was clearly some animosity from some individuals, often centring, as mentioned earlier, on sporting contests. In Rijeka, Sanja L (F, 113/4) related tales of the January 2012 handball game between Croatia and Serbia in Belgrade: the Serbian fans, she said, pointed laser beams at the Croatian players' eyes, and Želimir Ž (M, 13) and Sanja L (F, 11̌/4) talked of coin throwing and the breaking of car windows: "The hate shows in the sports games". Svjetlana M (F, 13/3/4) went on: "Those were only young people - they hadn't really experienced war, they'd just heard stories and I feel that they didn't have the right to do that'. More generally, Josip P (M, 151/2) in Zadar said he "didn't have problems with Serbs in general, but I don't like their war criminals". There were also some remarks dismissing cajke, the female singers of turbo-folk music, i.e. the commercial pop-influenced folk music from Serbia.

Asked about potential Serbian membership of the European Union, the discussion swayed between some mild gloating that Croatia would be a member country some years before Serbia, and an acceptance that they could and should become members. Petar M (M, 141/2) in Rijeka said: "We're a lot ahead of the Serbians! In the way that we've developed. Serbians need to do a lot of work to get to the point that we have had to". Agata N (F, 173/4) saw Croatian membership as "a big deal. We are part of the European Union, and they are not". Teo Z (M, 161/2) in Zagreb remarked "they attacked us - but they should join"; his friend Aiša V (F, $15 \frac{1}{2}$ ) agreed, even though "there are still people who would be negative about them joining". The above excerpts illustrate stereotypes in relation to Serbs and Serbia that evoke Todorova's (2009 [1997]) "balkanisation" narratives. These stereotypes utilise examples of the Balkan imagery (unsportsmanlike behaviour, war criminals, turbo-folk music, socio-economic and cultural underdevelopment) and use them as an implicit demarcation line between "us" and "them".

While there were some reservations, in Zagreb, Radoš B (M, 14³/4) thought some people would see Serbian membership as a possibility for Serbian domination, i.e. as an attempt to "boss them around, and that [they] will want to make a Greater Serbia", but that ultimately these opinions would not affect Serbia's accession to the European Union. Andrija P (M, $15 \frac{1}{4}$ ) said the war was twenty years ago - "we just have to let it go" and Blaženka M (F, 15) said "kids from Serbia who are our age, they didn't 
have anything to do with the war, and I think that they need to have the same opportunities as us, as we have". But in Zadar, Luka M (M, 143/4) instantly snapped back at the question: "No! I don't like Serbians. Because of the whole war thing that happened". There were probably more young people who accepted the concept of Serbian membership - in the future than those who were antagonistic about it, but because not everyone commented on the issue, one cannot be precise about this.

\subsection{Europeans or Balkanci?}

Civic identity and citizenship have been traditionally associated with a defined and exclusive area. This has become partially eroded through processes such as globalisation, large scale migration, and the development of dual citizenship (Castells, 2000 [1996], 2010 [1997]). Citizens of Croatia are now also citizens of the European Union, and this gives them rights and privileges beyond those provided by their country.

The young people we talked to drew a distinction between membership in the European Union and being European. Joining the EU divided opinions: many were cautious, but much the same number were cautiously in favour, which supports Ilišin et al.'s (2013) findings. Many comments concerned the financial implications of membership. Borna V (Rijeka, M, $\mathrm{u} / \mathrm{k}$, in a $12-14$ group) thought the point of joining was that the country would be financially supported by other countries, but he was concerned that "we might have to lend money to other countries". Zrinka B (Rijeka, F, 141/4) added that "if we go into Europe and we don't need any money to be given to us, then we'll have to give. [...] So if we get in, and some other country needs money, we will have to give - and as it is, we don't have a lot of money - so, it's tricky". Dalibor N (Zadar, M, 16) expected little change: "And if they change they will change for the worse - economics, basically economics". Zdenko Z (Zadar, M, 141/2) thought financial support was not enough: "Look at Greece - Greece also got aid from the European Union, and still it's in major problems".

There were some hopes that there would be positive changes - maybe "young people will have a better life and work, that everyone will have a place to work, that people won't be without a home", suggested Aleksandra M (Zadar, F, 15\%/4), but in the short term she expected to see little impact. This view was fairly common. Petar M (Rijeka, M, 141/2) looked not just to more employment, but that "we will be more connected to the European 
Union countries that are more developed than us". "They'll help us have better lives", said Želimir Ž (Rijeka, M, 13).

There were also expressions of fear. Aleksandra M (Zadar, F, 15\%3) pointed out "we are afraid to enter [...] because we've always been under someone's rule. It's only in the past twenty years that we've had our own state". Aiša V (Zagreb, F, 151/2) feared Europeans would move to Croatia and take jobs and buy all the property. There were also concerns for the future of the European Union: Branko K (Zadar, M, 161/2) compared the European Union to Yugoslavia - "Maybe even worse!", added Josip P (Zadar, M, 151/2).

But the European Union was also seen by some as a democratic force. Morana B (F, 143/4) in Zagreb thought joining the EU was an "opportunity to develop our democracy [...]. We should take it. Democracy is something I associate with Europe and the European Union. It depends on us: we are the ones who have to say we will do it, who will stick together [...]. Other people in Europe will see our qualities and they will understand us a lot better". In response to this, Vanda P (Zagreb, F, 15) felt "there's one problem about it here - we don't know who we are choosing, we are not educated about that aspect of government." In the above excerpts being European was represented (both in a positive and negative sense) with regard to its civic component (Bruter, 2005) whereby a common European entity might enable (or not) economic prosperity and the preservation of democracy. Besides this instrumental representation of Europe, in an emotional sense, that relates to Bruter's cultural component of identity, European identity stays incomplete and contradictory as shown below (cf. Waechter, 2016).

It is not possible to classify individual responses as being simply either positive or negative, toward identification with Croatia, the Balkans or Europe. Most individuals constructed their identifications in a variety of ways, responding to the particular contextual contingencies of the conversation at that particular moment. Was the lens through which the subject was being viewed one of comparison to other Balkan states, or to the imagined conditions of Western Europe? Was it part of a discourse that focussed on generational aspects of difference from what they thought were the views of their parents and grandparents, or part of a discussion about their perceptions of commonalities (or not) with Serbians?

The dominant discourse was mainly of a sense of difference from Europe. This difference was sometimes expressed as a sense of being left 
out of Europe. Zagreb might look like a European city, said Blaženka M (Zagreb, F, 15), "but in today's Europe, I don't feel that we are part of it, because we are left out". Andrija P (Zagreb, M, 15\%/4) distinguished the political from the cultural: "I personally feel like a part of cultural Europe, but because of being left out, I don't feel a part of political Europe". Such nuanced ambivalence seems to confirm Delanty and Rumford's (2005: 4) suggestion of the emergent salience of a European social and cultural space, as distinct from an institutional space.

The difference was also expressed as a difference in "ways of being". "Even if we enter Europe", said Dragan L (Zagreb, M, 143/4) "we will never be on that level of European society, because here, people are very different from other parts of Europe. We don't accept differences, different attitudes. For example, when Gay Pride was in Zagreb, people came just to throw stones. People in the Balkans are less tolerant than in other parts of Europe". Mladen D (Zadar, M, 15) thought it would be good "to be united with Europe - but the Croatian people are not European, they won't be united like other countries". This was a common expression: Lorena P (Zadar, F, 141/2) thought it "a good idea to become a member but it's also not good because we're not civilised enough"; "We need to be more organised", said Ružica L (Zadar, F, 141/2). According to Josip P (Zadar, M, 151/2): "We are Balkan, because we are different from the rest of Europe. We don't have similar behaviour [...]. They are more polite. We're quite impolite and loud - not all of us, but some of us". But he also suggested that becoming European was to loose one's Balkan identity: "They're trying to Europeanise us by force - but I hope that they don't succeed, because we should stay as we are. I don't feel European at all - I just feel Croatian, a Dalmatian, a Balkan". Josip P constructs here three identities that he uses, in this context, to define himself as not European, while Lorena assembles two variants of Europe, one of which she would like to identify with, the other which she constructs as excluding Croatians because of their presumed behaviour.

Another group, in the Zagreb vocational school, tried to locate where the "real" Europe was for them: they suggested Germany, Switzerland and France. Zagreb was just "a small town", said Teo Z (M, 161/2), while Marija M (F, 15\%/4) had been dreaming of Paris "since I was five - if people from Zagreb behaved like people from Paris, I think we would be [...] better! Maybe it's my imagination - but maybe they are more sophisticated than 
people from Zagreb". Ljubomir B's (Zagreb, M, 16) explanation was "because we are Balkanci" ${ }^{8}$ ". Marija M (F, 15\%/4) agreed: "People from the Balkans have a different culture and other people notice that". "The behaviour is different", said Ljubomir B (M, 16). Teo Z (M, 161/2) thought Croatia was "even worse Balkan than it was [...] new generations are worse and worse".

These excerpts illustrate a self-deprecating portrayal of intolerant, uncivilised, disorganised, impolite, unsophisticated and loud Croatian-Balkan people versus a tolerant, civilised, organised, sophisticated and polite Europe represented by countries of Western Europe such as Germany, Switzerland and France. In this sense, young people in Croatia see themselves in line with the dominant Western imagery of the Balkans (Todorova, 2009 [1997]). However, not all students shared this self-deprecation. There were conflicting perceptions of Croatia's position on the "developed (European)under-developed (Balkan)" continuum. In Zagreb, Vanda P (F, 15) argued Croatia was not Balkan. "There are some effects from other countries - we are middle-European, like Austria, even from the Ottoman wars, Turkey also Hungary - Italy too - so we are a mixture of everything, but we are unique in our own way". In Zadar, there were expressions of being Balkan: Josip P (M, 151/2) exclaims "I feel like a Balkan!", but Biserka K (F, 143/4) said she did not: "I think our country is more polite than other Balkan countries, and people are better".

There was a sense that the designation "Balkan" was imposed from the outside. The stigmatisation of the Balkans that Todorova (2009 [1997]) suggests is echoed by many of these young people. Želimir Ž (Rijeka, M, 13) said: "European people always group us in that culture, with Serbia, but we are not like that". In Rijeka, Vida B (F, 161/2) said: "They rank us as Balkans, the other people in Europe, and we have to live with that. It's a label, we live with this label. We try to distinguish that we are better than other Balkan people - and we say 'Yes, we are going to be part of the European Union - we are more European than you other Balkan people' - it's a bad thing to be called, Balkan people." Danijela F (Rijeka, F, $15^{3} / 4$ ) agreed: "They gave this label to us, so we kind of accept it, and are partly proud of it - and now we're going to be in Europe, and we don't

\footnotetext{
${ }^{8}$ Balkanci is a word in Croatian, Serbian and some other South-Slavic languages that literally means "people from the Balkans", but is also often used in a pejorative sense, even in self-identification.
} 
like other Balkans, because we think we are better than that". In Zagreb, Dubravka S (F, 15) talked of feeling that "other people, from the Western countries think you're primitive. Because we're from this part of Europe. We are kind of left out [of Europe] - the superstitions [prejudices] of other countries, the Western countries, still don't make you feel welcome there". Andrija P (Zagreb, M, 151/4) most clearly expressed a common perception: "No one wants to be part of the Balkans - for Croatians, the Balkans begin in Bosnia; in Bosnia the Balkans begin in Serbia; and in Serbia they begin in Romania - because of the prejudices of the Western countries". It was almost as if each person described themselves as standing on a line: if they faced north-west, they saw Europe, and to the south-east were the Balkans. Each saw themselves as standing on the threshold. Todorova (2009 [1997]) has described this as "nesting balkanisms", a tendency for each area to construct the cultures to the south-east as less civilised and more conservative. The gradient of nesting balkanisms (Elchinova, 2004; Todorova, 2009 [1997]) was evident: in Rijeka, Petar M (M, 141/2) saw Slovenia as "more of a European country than the [other] ex-Yugo countries - they are more developed than us [...] they moved on". In Zadar, Josip P (M, 151/2) explained that "Slovenians used to be Balkans, but now they've become Europeanised, they've become part of Europe". His colleague Mladen D (M, 15) nuanced this: the Slovenians "are Balkans, but they are much more European, more European than we are [...] they behave like Europeans they are calm, they are polite".

The dynamic nature of "Europe" and "the Balkans" is even more salient when the two are regarded as identity constructions. As such, they are still opposed to each other, for the Balkans are not alien to Europe, they are its "darker side" or incomplete self (Elchinova, 2004: 37).

\section{Discussion and conclusions}

Researching youth identities as we did has its limitations. Although discussions among peers can provide insights unique to focus groups as a research method, probing personal opinions in more depth is restricted. For instance, students in our study often drew on stereotypical representations of "others" and since stereotypes refer to generalisations of traits that are observed in some members of a group to all members of the group, regardless of actual variation among members (Koren, 2013), they tend to simplify complex issues. Unpicking this centrality of stereotyping in our study 
would therefore benefit from additional individual interviews with our focus group participants. Another limitation may be related to the overall theoretical framework of the study which guided data collection in different European countries. Due to this international study design, more complex national specificities may have been overlooked, though we have tried to address this by reference to local authors where applicable.

The young people from our study stand at the threshold between traditionally structured place identifications and a new way of political and cultural expression related to European Union membership. The Croatian identity is cultural, predominantly, but is also political for the young people in our study - not so much in terms of political institutions, but in the political character of the independent state, established in the Homeland War. Bruter's civic and cultural components of identity were both evident in their constructions of the country. Regional identities were also strong, and these seemed to echo the historical fragmentation of the country - such as the way in which the coastal groups distinguished themselves from the "continentals". These country and regional identities were multiple and fluid: as the lens of the discussion moved from their perceptions of their city to the country as a whole, so different place identifications were foregrounded.

The geographical borders of the various place identifications we explored operate as points of symbolic separation and articulation at which ethnic and other forms of stereotypes are created (Bennington, 1990, in Šakaja, 2001). The nature of being Balkanci was articulated by most of these young people as essentialist, a reality that could not be compatible with Europeanness. Todorova's nesting balkanism has echoes of Said's (1978) orientalism. Bakić-Hayden and Hayden (1992: 4) use the term "nested orientalism" to describe the hierarchical construct of the Eastern. The young people from our study expressed a common sense of the Balkan-European divide being a line that stood very slightly to the north-west of wherever we happened to be talking: there was Europe, generally beckoning - but Croatia was portrayed as on a threshold, though still leaning towards the Balkan side: underdeveloped, with littered streets and quarrelsome people. These young people were aware, in a way, of the transitional nature and liminality of their situation, but consistently described themselves as not yet having moved over the threshold. Although they appeared to recognise that they, and their generation, cross the boundaries of constructed categories, they also showed a sense of being not-quite-yet European. Croatia's "Europeanness" seemed 
more pronounced only in relation to Croatia's eastern borders, mainly Serbia, which was then positioned as the "true" Balkan. Such perception of the Serbs "as more Balkan" - apart from more recent war experiences - echoes historical representations of Croatian identity as metaphysically inclined towards the West that simultaneously projected the Balkans "as the darkest side of human civilisation in this part of the world" (Katunarić, 1997: 14). Although these representations can be related to historical developments that followed the Ottoman invasion of the Balkan Peninsula (Katunarić, 1997), they may still be reflected in modes of cultural stereotyping in relation to Croatia's eastern neighbours (Serbia, Bosnia and Herzegovina and Montenegro) and other Balkan countries (Katunarić, 2007: 187-194; Koren, 2013).

Europe was, as an entity on its own, seen primarily as political - it was over there, offering financial mutual support, travel opportunities and education. For some of these young people, Europe was a problematic construct. It was in some senses a desirable attainment, but as yet not achieved, and at the same time had an exclusiveness that meant that they felt as outsiders. Europe was thus seen only partly as cultural. With regard to European culture that they "ought" to share, there was some uncertainty which seemed to encompass activities from financial probity to being conscious not to litter the streets - where it was felt that they fell short. But Europe was also more prominently seen as institutional, and in this aspect there was a greater sense of focus and of anticipation. In terms of Bruter's perspectives, Europe was more firmly constructed as a civic entity, rather than a cultural one, whereas the Balkans appear as more of a cultural entity. In an emotional sense, Europe remained distant, cut off partly by the attitude of "other" Europeans to them, partly by their distrust of their own "mentality". Research findings from other European countries suggest that emotional distance towards Europe may be a more universal phenomenon (Bruter, 2005). As such it may explain why among young people in Europe "European identity is least important compared to identification with their location or their nation of residence or origin (Jamieson 2005; Macháček 2004; Spannring, Waechter, and Datler 2005; Waechter and Samoilova 2012)" (Waechter, 2016: 287). Importantly though, and going back to our interest in intersectionality as an analytical strategy which rejects the separability of identity categories, we found that regionality, country affiliation, as well as various senses of being on a European-Balkan spectrum coexisted in shaping complex place identifications. 
This study thus suggests that many Croatian young people may be developing complex and kaleidoscopic constructions of themselves as having a variety of social and political identities - within the regions of Croatia, Croatia itself, Croatia within the Balkans, and Europe. In 2010 Joppke (2010: 30) noted a lack of qualitative empirical studies on the nature of civic identities: a number of forthcoming projects seek to help address the aspects of this issue (for example, a special issue of the journal Qualitative Psychology on qualitative methodologies in the study of citizenship and migration, to appear in late 2017, and the Cohesive project currently in progress at the European Policy Research Centre at University of Strathclyde, which will report in 2018). There is a plethora of quantitative studies (such as the Eurobarometer series of opinion studies), but these ask simplistic and context-free questions that can only be responded to within a predetermined and limited framework of essentialised categories. This study contributes to a wider analysis of the processes of identity construction that acknowledges the multiplicity of identities that people adopt, the contingency of their construction in terms of place, time, context and situation, and the plasticity of their responses. In some respects, these Croatian findings fit within a wider European framework of globalisation and localisation, in other respects they are similar to findings in other countries in the same geographical region of Europe (Macedonia, Bulgaria, parts of Romania and of Slovenia), and in other ways they are specific to Croatia (Ross, 2018, forthcoming).

In a study on young adults' orientation to citizenship and European identity, Grundy and Jamieson opposed a small group who "come to present themselves as passionate utopian Europeans" to a majority of 18 to 24 year-olds from their study for whom "being European remains emotionally insignificant and devoid of imagined community or steps towards global citizenship" (Grundy and Jamieson, 2007: 663). Those who did not feel a strong European identity ranged from those who were mildly positive or agnostic about the European Union to the ones who actively distanced themselves from the EU (Grundy and Jamieson, 2007, 670): they were "absent-minded", in the sense of not having any sense of "being European" in their everyday thoughts. Our findings suggest that very few of the young people we talked to could be characterised as "absent-minded" about any of their multiple, intersecting place identifications. The Grundy and Jamieson findings of a passionate -absent-minded spectrum of atti- 
tudes towards Europe was less polarised in the views of the young people we spoke to: they were nearly all interested and engaged in discussing their many senses of belonging. In this interchange of perspectives, narratives of modernisation and "Europeanness" did not exclude those of the "Balkan-mentality" or the nation as a primordial given. Rather, it was evident that these opposed components coexist in the identity constructions of the young people in our study. Although from a democratic standpoint it is not clear if such a finding represents a cause for optimism or pessimism (cf. Katunarić, 1994), it certainly provides a dynamic element for future social relations in Croatia.

\section{REFERENCES}

Bakić-Hayden, Milica and Hayden, Robert (1992). "Orientalist variations on the theme 'Balkans': Symbolic geography in recent Yugoslav cultural politics", Slavic Review, 51 (1): 1-15. doi: 10.2307/2500258

Bar-Tal, Daniel (1997). "Formation and Change of Ethnic and National Stereotypes: An Integrative Model", International Journal of Intercultural Relations, 21 (4): 491-523. doi: 10.1016/S0147-1767(97)00022-9

Baranović, Branislava (2002) "Mladi u Hrvatskoj - između nacionalnog identiteta i europske integracije" [Youth in Croatia - Between National Identity and European Integration], in: Vlasta Ilišin and Furio Radin (eds.). Mladi uoči trećeg milenija [Youth on the Eve of the Third Millennium]. Zagreb: Institut za društvena istraživanja u Zagrebu, pp. 125-154.

Bauman, Zygmunt (1997). Postmodernity and Its Discontents. Cambridge: Polity Press.

Boehnke, Klaus and Fuss, Daniel (2008). "What Part Does Europe Play in the Identity Building of Young European Adults?", Perspectives on European Politics and Society, 9 (4): 466-479. doi: 10.1080/15705850802416887

Bruter, Michael (2003). "Winning hearts and minds for Europe: The impact of news and symbols on civic and cultural European identity", Comparative Political Studies, 36 (10): 1148-1179. doi: 10.1177/0010414003257609

Bruter, Michael (2004). "On what citizens mean by feeling "European": Perceptions of news, symbols and borderless-ness", Journal of Ethnic and Migration Studies, 30 (1): 21-39. doi: 10.1080/1369183032000170150

Bruter, Michael (2005). Citizens of Europe? The Emergence of a Mass European Identity. London: Palgrave Macmillan. doi: 10.1057/9780230501539

Bruter, Michael (2008a). "In the face of Europe: Citizens, symbols, and European identity", in: Thomas Meyer and Udo Vorholt (eds.). Identität in Europa. Dortmunder politisch-philosophische Diskurse (6). Bochum: Projekt Verlag.

Bruter, Michael (2008b). "Legitimacy, Euroscepticism and Identity in the European Union - Problems of Measurement, Modelling \& Paradoxical Patterns of Influence", Journal of Contemporary European Research, 4 (4): 273-285. 
Bruter, Michael (2009). "Time bomb? The dynamic effect of news and symbols on the political identity of European citizens", Comparative Political Studies, 42 (12): 1498-1536. doi: 10.1177/0010414009332465

Castells, Manuel (2000 [1996]). The Rise of the Network Society, 2nd Edition. Oxford: Blackwell. doi: 10.1002/9781444319514

Castells, Manuel (2010 [1997]). The Power of Identity, 2nd Edition. Oxford: Blackwell. doi: 10.1002/9781444318234

Connor, Walker (1978). "A nation is a nation, is a state, is an ethnic group, is a ...", Ethnic and Racial Studies, 1 (4): 379-388. doi: 10.1080/01419870.1978.9993240

Crenshaw, Kimberle (1991). "Mapping the margins: Intersectionality, identity politics, and violence against women of color", Stanford Law Review, 43 (6): 1241-1299. doi: 10.2307/1229039

Delanty, Gerald and Rumford, Chris (2005). Rethinking Europe: Social Theory and the Implications of Europeanization. London: Routledge. doi: $10.4324 / 9780203640050$

Elchinova, Magdalena (2004). "Bulgaria's way to Europe: Some aspects of identity construction among Bulgarian students today", Ethnologia Balkanica, 8 (1): $35-55$.

Grundy, Sue and Jamieson, Lynn (2007). "European identities: From absentminded citizens to passionate Europeans", Sociology, 41 (4): 663-680. doi: $10.1177 / 0038038507078919$

Hilton, L. James and Von Hippel, William (1996). "Stereotypes”, Annual Review of Psychology, 47: 237-271. doi: 10.1146/annurev.psych.47.1.237

Ichilov, Orit (2005). "Pride in One's Country and Citizenship Orientations in a Divided Society: The Case of Israeli Palestinian Arab and Orthodox and NonOrthodox Jewish Israeli Youth", Comparative Education Review, 49 (1): 44-61. doi: $10.1086 / 426160$

Ilišin, Vlasta, Bouillet, Dejana, Gvozdanović, Anja and Potočnik, Dunja (2013). Mladi u vremenu krize [Youth in Time of Crisis]. Zagreb: Institut za društvena istraživanja u Zagrebu and Friedrich Ebert Stiftung.

Jensen, Sune Qvotrup (2011). “Othering, identity formation and agency”, Qualitative Studies, 2 (2): 63-78.

Joppke, Christian (2010). Citizenship and Immigration. Cambridge: Polity.

Judt, Tony (2005). Postwar: A History of Europe since 1945. London: Heinemann.

Katunarić, Vjeran (1994). Labirint evolucije [Labyrinth of Evolution]. Zagreb: Hrvatsko sociološko društvo.

Katunarić, Vjeran (1997). "National Identity and Behavioural Patterns", in: Vjeran Katunarić (ed.). Multicultural Reality and Perspectives in Croatia. Zagreb: Interkultura, pp. 13-28.

Katunarić, Vjeran (2007). Lica kulture [The Faces of Culture]. Zagreb: Antibarbarus.

Koren, Deja (2013). Istraživanje nacionalnih autostereotipa i heterostereotipa: što Hrvati misle o sebi, Slovencima i Srbima? [A Study of National Self-Stereotypes and Hetero-Stereotypes: What Do Croats Think about Themselves, Slovenians and Serbs]. Zagreb: Filozofski fakultet Sveučilišta u Zagrebu. 
Kristeva, Julia (2000). The Crisis of the European Subject. New York: Other Press. Marić, Dea (2016). "The Homeland War in Croatian History Education: Between 'Real Truth' and Innovative History Teaching", in: Denise Bentrovato, Karina V. Korostelina and Martina Schulze (eds.). History Can Bite: History Education in Divided and Postwar Societies. Gottingen: V\&R unipress, pp. 85-109. doi: 10.14220/9783737006088.85

Marshall, Catherine and Rossman, Gretchen B. (1999). Designing Qualitative Research. London: Sage.

McCall, Leslie (2005). "The complexity of intersectionality", Journal of Women in Culture and Society, 30 (3): 1771-1800. doi: 10.1086/426800

Menard, Louis (2005). "From the ashes: A new history of Europe since 1945", New Yorker, November 28. http://www.newyorker.com/magazine/2005/11/28/ from-the-ashes.

Rabiee, Fatemeh (2004). "Focus-group interview and data analysis", Proceedings of the Nutrition Society, 63 (4): 655-660. doi: 10.1079/pns2004399

Radin, Furio (2005). "Nacionalna vezanost i odnos prema Europi [National Identification and Relation towards Europe]", in: Vlasta Ilišin (ed.). Mladi Hrvatske $i$ europska integracija [The Youth in Croatia and the European Integration]. Zagreb: Institut za društvena istraživanja u Zagrebu, pp. 173-195.

Renan, Ernest (1994 [1882]). “Qu'est-ce qu'une nation?”, in: John Hutchinson and Anthony D. Smith (eds.). Nationalism. Oxford: Oxford University Press, p. 17.

Ritzer, George (2007 [2003]). Contemporary Sociological Theory and Its Classical Roots: The Basics. Boston: McGraw-Hill.

Ross, Alistair (2015). Understanding the Construction of Identities by Young Europeans: Kaleidoscopic Selves. London: Routledge. doi: 10.4324/9781315886800

Ross, Alistair (2018, forthcoming). Finding political identities: Young people in a changing Europe. London: Palgrave Macmillan.

Said, Edward W. (1978). Orientalism. New York: Vintage.

Schlenker, Andrea (2007). Multiple Identities in Europe: A Conceptual and Empirical Analysis. Paper presented at the EU-CONSENT Fifth Meeting, "Democracy, Legitimacy and Identities: Citizens and the Construction of Europe". http://www.eu-consent.net/library/PhD/Schlenker.pdf.

Sekulić, Duško and Šporer, Željka (2008). "European and Croatian Identity: Cognitive Mobilization or Latent Conflict", Sociologija i prostor, 46 (1): 3-22.

Stevick, Doyle and Levinson, Bradley A. U. (2007). Reimagining Citizenship Education: How Diverse Societies Form Democratic Citizens. Lanham: Rowman and Littlefield.

Smithson, Janet (2000). "Using and analysing focus groups: Limitations and possibilities", International Journal of Social Research Methodology, 3 (2): 103-119. doi: 10.1080/136455700405172

Šakaja, Laura (2001). "Stereotipi mladih Zagrepčana o Balkanu: Prilog proučavanju imaginativne geografije" [Stereotypes among Zagreb Youth Regarding the Balkans: A Contribution to the Study of Imaginative Geography], Revija za sociologiju, 32 (1-2): 27-37.

Todorova, Maria (2009 [1997]). Imagining the Balkans. Oxford: Oxford University Press. 
Twigger-Ross, Clare L. and Uzzell, David L. (1996). "Place and identity processes”, Journal of Environmental Psychology, 16 (3): 205-220. doi: 10.1006/ jevp.1996.0017

Waechter, Natalia (2016). "Formation of European identity: Ethnic minority groups in Central and Eastern Europe in generational perspective", Identities, 23 (6): 686-704. doi: 10.1080/1070289x.2015.1059340

Waldron, Jeremy (2000). "Cultural identity and civic responsibility", in: Will Kymlicka and Wayne Norman (eds.). Citizenship in Diverse Societies. Oxford: Oxford University Press, pp. 155-174. doi: 10.1093/019829770X.003.0006

Wiborg, Agnete (2004). "Place, Nature and Migration: Students' Attachment to their Rural Home Places", Sociologica Ruralis, 44 (4): 416-432. doi: 10.1111/j.1467-9523.2004.00284.x

Wolff, Larry (1994). Inventing Eastern Europe: The Map of Civilization on the Mind of the Enlightenment. Stanford: Stanford University Press.

\title{
Balkanci i Europejci? Mjesni identiteti mladih u Hrvatskoj
}

\author{
Alistair ROSS \\ London Metropolitan University, Ujedinjeno Kraljevstvo \\ alistairrosslondon@gmail.com \\ Saša PUZIĆ \\ Institut za društvena istraživanja u Zagrebu, Hrvatska \\ puzic@idi.hr
}

Karin DOOLAN

Odjel za sociologiju, Sveučilište u Zadru, Hrvatska

kdoolan@unizd.hr

U radu se ispituje kako mladi u Hrvatskoj konceptualiziraju svoje identitete $\mathrm{u}$ vidu »mjesnih identiteta« kao vrste društvene identifikacije koja obuhvaća pripadnost društvenoj skupini koja se definira njezinom lokacijom. Rad se temelji na podacima prikupljenima u okviru fokusnih grupa u kojima je sudjelovalo 68 učenika i učenica osnovnih i srednjih škola u dobi između 11 i 17 godina u trima gradovima u Hrvatskoj: Rijeci, Zagrebu i Zadru. Konceptualni okvir analize uključuje mjesne identitete, građansku i kulturnu komponentu nacionalnog identiteta i intersekcionalnost. Analiza pokazuje da učenici i učenice izražavaju snažan regionalni identitet u kojem značajno mjesto zauzimaju stereotipi koji se odnose na razlike između priobalja i unutrašnjosti, između ruralnih i urbanih područja te između sjevera i juga. Nacionalni kulturni identiteti i rubni europskobalkanski identiteti podjednako su snažni te pružaju zanimljive primjere inkluzije i isključivanja »drugog i drukčijeg«. Mladi obuhvaćeni istraživanjem izražavaju 
istodobno težnju k europejstvu, osjećaj nepotpunog odnosno još nedostignutoga europejstva, kao i osjećaj pripadnosti balkanskome kulturnom krugu. Analiza je pokazala i zajedničko razumijevanje podjele između Europe i Balkana shvaćene kao razdjelnice koja se nalazi uvijek sjeverozapadno u odnosu prema lokalitetu učenika: iako po pravilu teže Europi, učenici još nisu prešli europski »prag« te su još uvijek »nagnuti« prema Balkanu, koji se prikazuje kao nepristojan, svadljiv, nerazvijen i neuredan. Na tom tragu, autori upućuju na složene i kaleidoskopske identitetske konstrukcije mladih u Hrvatskoj, u kojima se različiti i suprotstavljeni elementi međusobno ne isključuju, nego koegzistiraju na različite načine.

Ključne riječi: mjesni identitet, građanski i kulturni identiteti, intersekcionalnost, mladi, Hrvatska, Balkan, Europa 